\title{
需要予測におけるマニピュレーション抑止制度の比較分析* Comparative Analysis on Manipulation Preventing Mechanism of Demand Forecast *
}

\author{
福本潤也** \\ By Jun-ya FUKUMOTO**
}

\section{1.はじめに}

社会資本を整備する前段において，一般に何らか の予測作業が求められる．道路を新規建設する場合 には需要予測の分析結果に基づいて設計仕様の妥当 性の検討や事業代替案の選択が行われる．P F I 事 業の場合には将来の不確実な事象についての予測結 果をもとに各種主体が負担する費用やリスクの配分 が行われる．予測は合理的な政策策定のために不可 欠な作業であるといっても過言ではない.ただし， 社会基盤施設整備をめぐる予測作業が様々な困難性 を抱えているのも事実である. 複雑な社会現象を対 象としているため，正確な予測がきわめて困難であ るというのは典型例の一つである. それ以外にも， 予測作業の方法論が複雑であり, 分析内容をめぐつ て各種主体間で情報の非対称性が発生しやすいとい った困難性や，予測作業を必要とする公共事業に 様々な利害関係者が関わってくるため，予測作業を 担う分析者に染意的操作（マニピュレーション）を 行う圧力がかけられやすいといった困難性がある.

国土交通省が実施した交通需要推計 ${ }^{1)}$ に対する猪 瀬直樹氏の問題提起 ${ }^{2)}$ に見られるとおり，行政が事 業実施を正当化するために需要予測においてマニピ ユレーションを行っているのではないかとの社会的 不信感には根強いものがある。これに対し，筆者は 需要予測におけるマニピュレーションを未然に抑止 する制度設計に関する研究にこれまで取り組んでき $た^{3), 4)}$. 契約の経済理論 ${ }^{55-9)}$ の分析枠組みを援用する ことで, 需要予測の分析者への報酬を事後的に観察 された状態（事後的に観察された交通量など）の事 前予測確率に連動させる制度（以下，リスク負担制 度と呼ぶ）を導入することでマニピュレーションを 抑止することが可能になるとの分析結果を既に導き 出している．ただし，リスク負担制度は，あくまで 一定の前提条件のもとで導出される制度に過ぎない. 前提条件が変更された場合には，その他のマニピュ レーション抑止制度が導出される可能性は十分にあ る. 需要予測のマニピュレーション問題への社会的 関心の高さを踏まえると，様々な制度を考案したう

*キーワード: 公共事業評価法, 財源・制度論, 計画情報

$* *$ 正員工博 日本学術振興会特別研究員

T113-0033 文京区本郷 7-3-1, TEL\&FAX:03-5841-6116 e-mail: fukumoto@trip.t.u-tokyo.ac.jp
えで，社会的に受容されやすい制度を検討すること の社会的必要性はきわめて大きいと考えられる，以 上の問題意識に鑑み，本稿では，需要予測における マニピュレーション抑止制度の代替案を複数提示し, それぞれの制度の性質を理論的に比較検討すること を試みる。

マニピュレーション抑止制度の設計にあたり，重 要となる視点の一つに予測をめぐるリスクの配分が ある，予測をめぐるリスクは，分析を行うまでいか なる予測結果が得られるか分からないという意味で のリスクと，予測結果が得られた後でもいかなる将 来状態が実現するか分からないという意味でのリス クの二種類から構成されている．2つのリスクをい かに配分するかでマニピュレーション抑止制度の効 率性も大きく変わってくる可能性がある. また，現 時点において行政が実施する予測作業を下請けして いるコンサルタンツの多くはリスク許容度が一般に 小さいと考えられている。リスクをいかに配分する かでマニピュレーション抑止制度の社会的受容性も 大きく変わってくる可能性がある，以下では，予測 をめぐるリスクの配分に特に注意しながら, 複数の マニピュレーション抑止制度を比較することを試み る.

論文構成は次のとおりである，2．では，複数の 制度を比較検討するための共通枠組みとして用いら れる道路投資・需要予測問題を定義する. 3. では, 筆者らの先行研究 ${ }^{3), 4)}$ をとにリスク負担制度を解 説する，4，から 8. では, 有限責任制度, トーナ メント制度, 繰り返し取引き制度, 再交渉制度, 監 查制度の 5 つを 1 つずつ取り上げ，それぞれの性質 について検討する．9.では, 分析結果を総括する.

\section{2. 道路投資 $\cdot$ 需要予測問題}

\section{（1）道路投資問題}

複数のマニピュレーション抑止制度を比較するた めに, 本稿では先行研究 ${ }^{3)}$ で取り上げた次の道路投 資問題を例題として用いることにする.

分析対象となるのは一本の道路である. 道路利用 者の需要関数を

$$
q=a(\bar{p}-p)
$$

で表す.ただし，qは需要量， $p(\leq \bar{p})$ は一般化費用， $\bar{p}$ とaはパラメータである. パラメータ $a$ は二值確 


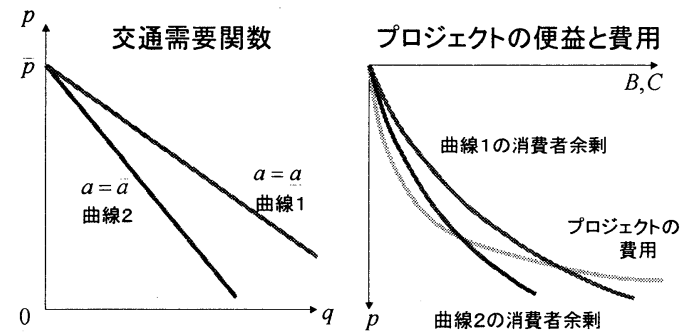

図-1 道路投資問題

率変数であり, $a=\underline{a}$ もしくは $a=\bar{a}$ のいずれかの值 をとるものとする（ただし， $0<\underline{a}<\bar{a}$ ) . パラメー 夕は有限閉区間の連続変数であるとしても, 以下の 議論は同様に行うことができるが，本稿では分析の 簡単化を優先する. さて, 一般化費用が $p$ で与えら れる場合, 道路利用者の消費者余剩は

$$
B(p, a) \equiv \frac{a}{2}(\bar{p}-p)^{2}
$$

と表される.ここで, 道路の一般化費用を $\bar{p}$ から $p$ へ変更する道路投資問題を考える. 投資費用を

$$
C_{I}(p) \equiv \frac{b}{3}(\bar{p}-p)^{3}
$$

で表す．ただし， $b$ はパラメータである，以上の関 係は図-1に示されるとおりである.

\section{（2）需要予測問題}

道路投資問題に関わる主体として国民と分析者の 二人を考える．国民は消費者余㮃から投資費用を引 いた社会的純便益を最大化する投資水準 (一般化費 用の水準) の実現を望んでいる. パラメータ $a$ につ いての初期信念 (主観的確率) $P(\underline{a})$ および $P(\bar{a})$ で 表すと, 国民が解くべき最適道路投資問題は

$$
\max _{p}\left[P(\underline{a}) B(p, \underline{a})+P(\bar{a}) B(p, \bar{a})-C_{I}(p)\right]
$$

と定義される. この問題を解くことで, 最適投資水 準と期待社会的純便益が次のとおり導かれる.

$$
\begin{gathered}
p^{*}(\phi) \equiv \bar{p}-\frac{P(\underline{a}) \underline{a}+P(\bar{a}) \bar{a}}{b} \\
\operatorname{ESNB}^{*}(\phi) \equiv \frac{(P(\underline{a}) \underline{a}+P(\bar{a}) \bar{a})^{3}}{6 b^{2}}
\end{gathered}
$$

ここで， $\phi$ は以下で説明する需要予測が一切行われ ていないことを意味する記号である。

式(5)の最適投資水準は, 国民がパラメータ、につ いて有する初期信念から導出されるものである.よ り精度の高い予測が可能であるならば適切な投資水 準の選択を通じて期待社会的純便益が増加する．た だし，国民は需要予測を自ら行うことはできない
表-1 同時生起確率

\begin{tabular}{|c|c|c|}
\hline & $\underline{d}$ & $\bar{d}$ \\
\hline$\underline{a}$ & $\frac{1+\kappa \theta}{4}$ & $\frac{1-\kappa \theta}{4}$ \\
\hline $\bar{a}$ & $\frac{1-\kappa \theta}{4}$ & $\frac{1+\kappa \theta}{4}$ \\
\hline
\end{tabular}

ものとする. 代わりに, 需要予測を行うことができ る分析者に需要予測を委託する状況を考えてみる.

分析者は, 分析を通じて得られた情報に基づいて 需要予測を行うものとする. 分析で得られる情報は $\underline{d}$ もしくは $\bar{d}$ の 2 種類のいずれかであり, パラメー 夕 $a$ と分析で得られる情報 $d$ の同時生起確率が表-1 で表されるものとする.ただし， $\theta \in[0,1 / \kappa]$ は分析 の水準を表す変数, $\kappa \geq 1$ は分析者の能力を表すパラ メータである. なお, 以降の議論では, 「分析を通 じて得られた情報」を「調查を通じて観測されたデ 一夕」と読み替えても全く同様の議論を行うことが できる．この場合，情報 $d$ の具体例としては SP 調 查で「所要時間が○分短縮された場合に当該交通機 関を利用するか利用しないか」との質問に対する回 答割合が，パラメータ $a$ の具体例としては交通需要 の所要時間弾力性などが考えられる.

分析者にとって水準 $\theta$ の分析に要する費用を

$$
C_{S}(\theta) \equiv c \theta^{2}
$$

で表し（ただし， $c>0$ はパラメータ）, 分析者が需 要予測を行って予測結果を報告する代価として国民 から受け取る報酬を確率変数 $\omega$ で表すと, 分析者の 期待効用が

$$
E_{\omega}[u(\omega)]-C_{S}(\theta)
$$

と表される.ただし， $E_{X}[\cdot]$ は確率変数 $X$ に関する 期待值オペレータ, $u(\omega)$ は危険回避的な効用関数で ある. 分析者の報酬を確率変数で表すのは, 事後的 に観察される予測結果の当否などによって報酬が変 化する可能性を表現するためである. 分析者が国民 から予測業務を受託するのは, 期待効用が留保水準 $\underline{U}$ を上回る場合, すなわち参加制約条件

$$
E_{\omega}[u(\omega)]-C_{S}(\theta) \geq \underline{U}
$$

が満たされる場合である.

\section{（3）ファーストベスト解}

分析者が選択する分析水準 $\theta$ と分析を通じて得る 情報 $d$ のつが国民にとっても観察可能かつ立証可 能な情報である場合（すなわち, 国民と分析者の間 に情報の非対称性が存在しない場合），国民は分析 者に予測業務を委託することで期待社会的厚生（定 
義後述）を増加させることができる．まず，この点 を確認しておきたい.

分析者が水準 $\theta$ の分析を行った結果として, 情報 d を得たものとする.この時，最適道路投資問題は

$$
\max _{p}\left[\frac{1+\kappa \theta}{2} B(p, \underline{a})+\frac{1-\kappa \theta}{2} B(p, \bar{a})-C_{I}(p)\right]
$$

と定義され，最適投資水準と期待社会的純便益が

$$
\begin{array}{r}
p^{*}(\theta, \underline{d}) \equiv \bar{p}-\frac{(1+\kappa \theta) \underline{a}+(1-\kappa \theta) \bar{a}}{2 b} \\
\operatorname{ESNB}^{*}(\theta, \underline{d}) \equiv \frac{\{(1+\kappa \theta) \underline{a}+(1-\kappa \theta) \bar{a}\}^{3}}{48 b^{2}}
\end{array}
$$

と表される。一方, 情報 $\bar{d}$ を得た場合，同様に最適 投資水準と期待社会的純便益が，

$$
\begin{gathered}
p^{*}(\theta, \bar{d}) \equiv \bar{p}-\frac{(1-\kappa \theta) \underline{a}+(1+\kappa \theta) \bar{a}}{2 b} \\
\operatorname{ESNB}^{*}(\theta, \bar{d}) \equiv \frac{\{(1-\kappa \theta) \underline{a}+(1+\kappa \theta) \bar{a}\}^{3}}{48 b^{2}}
\end{gathered}
$$

と表される．分析を行う前の段階では分析を通じて いかなる情報が得られるか分からない，表-1 より， いずれの情報が得られる確率も 0.5 で与えられるた め, 水準 $\theta$ の分析実施前段階における期待社会的純 便益が

$$
\operatorname{ESNB}^{*}(\theta) \equiv \frac{1}{2} \operatorname{ESNB}^{*}(\theta, \underline{d})+\frac{1}{2} \operatorname{ESN}^{*}(\theta, \bar{d})
$$

と定義されることがわかる．ここで，国民は，道路 整備から享受する期待社会的純便益と分析者への期 待報酬支払いの差として定義される期待社会的厚生 を最大化す心゙く，分析者に実施すべき分析水準と予 測業務に対する報酬を提示するものと仮定する。こ の時, 対称情報下における最適需要予測問題が

$$
\begin{gathered}
\max _{\theta \in[0,1 / \kappa], \omega} \operatorname{ESNB}^{*}(\theta)-E_{\omega}[\omega] \\
\text { s.t. } \quad E_{\omega}[u(\omega)]-C_{S}(\theta) \geq \underline{U}
\end{gathered}
$$

と定義される. 式(16)は国民の目的関数，式(17)は分 析者の参加制約条件である.この問題を解くことで, 最適分析水準と計画者への最適報酬が次のとおり導 かれる.ただし， $\varphi(u)$ は $u(\omega)$ の逆関数である.

$$
\begin{gathered}
\theta^{*} \equiv \min \left\{\frac{(\bar{a}-\underline{a})^{2}(\bar{a}+\underline{a})}{24 b^{2} c} \kappa^{2}, \frac{1}{\kappa}\right\} \\
\omega^{*} \equiv \varphi\left(c\left(\theta^{*}\right)^{3}\right)
\end{gathered}
$$

式(19)より，対称情報下の最適契約においては分析 者が定額報酬を受け取り，予測に起因するリスクを 全く負担しないことがわかる. 国民が享受する期待 社会的厚生は,

$$
E S W^{*} \equiv \operatorname{ESNB}^{*}\left(\theta^{*}\right)-\omega^{*}
$$

と表される.

式(16)-(17)に $\theta=\omega=0$ を代入すると, 参加制約条 件が満たされ，国民の期待社会的厚生が式(6)に等し くなることが確認される. しかし, 最適需要予測問 題の定義より, $E S W^{*}>\operatorname{ESNB}^{*}(\phi)$ が常に成立するた め, 対称情報下では, 国民は分析者に需要予測を委 託することで期待社会的厚生を常に増加させること が可能であるといえる.

本節では分析水準と分析を通じて得られる情報の 2つを分析者の他に国民も確認することができると 仮定してきた。しかし，予測作業の方法論は一般に 複雑であり, 分析者以外の人間が分析内容の詳細を 理解することは困難であると考えられる．次節以降 では，国民が分析水準と分析で得られた情報の 2 つ を確認することができないとの意味で情報の非対称 性が存在する状況を想定して議論を進めていく.

\section{3.リスク負担制度}

\section{（1）分析の概要}

筆者らは先行研究 ${ }^{3), 4)}$ において, マニピュレーショ ン抑止問題が契約の経済理論で研究されてきたモラ ルハザード問題と類似の特徵を有している点に着目 することでリスク負担制度を導出した．以下，そこ で得られた知見を2.で定義した道路投資・需要予 測問題に即して解説する.

リスク負担制度では, 分析者に支払う報酬を事後 的に実現する状態に連動させることで，分析者にも 予测に起因するリスクの一部を負担させる．報酬を 適切に設計することで, 分析者に質の高い分析を行 うインセンティブと分析結果を正直に報告するイン センティブを与えることが試みられる. 事後的に状 態 $a$ が実現した場合に，予測結果の報告段階におい て水準 $\theta$ の分析を通して情報 $d$ を得たと報告した分 析者に事後的に支払う報酬を $\omega(a \mid \theta, d)$ と表すと, リ スク負担制度を有効に機能させる報酬が次の最適契 約問題の解として定義される ${ }^{3)-4), 10)-12) . ~}$

$$
\begin{aligned}
& \max _{\theta \in[0,1 / \kappa], \omega(a \mid \theta, d)} \operatorname{ESNB}^{*}(\theta)-E_{d}\left[E_{a}[\omega(a \mid \theta, d)]\right] \\
& \text { s.t. } \\
& E_{d}\left[E_{a}[u(\omega(a \mid \theta, d)) \mid \theta, d]\right]-C_{S}(\theta) \geq \underline{U} \\
& E_{d}\left[E_{a}[u(\omega(a \mid \theta, d)) \mid \theta, d]\right]-C_{S}(\theta) \\
& \geq E_{d}\left[E_{a}\left[u\left(\omega\left(a \mid \theta^{\prime}, d\right)\right) \mid \theta^{\prime}, d\right]\right]-C_{S}\left(\theta^{\prime}\right){ }^{\forall} \theta^{\prime} \in[0,1 / \kappa] \\
& \\
& E_{a}[u(\omega(a \mid \theta, d)) \mid \theta, d] \\
& \geq E_{a}\left[u\left(\omega\left(a \mid \theta^{\prime}, d^{\prime}\right)\right) \mid \theta, d\right]{ }^{\forall} d^{\prime} \in\{\underline{d}, \bar{d}\},{ }^{\forall} \theta^{\prime} \in[0,1 / \kappa]
\end{aligned}
$$

式(22)は分析者の参加制約条件, 式(23)は分析水準の 選択に関する誘因整合性条件, 式(24)は分析結果の 正直な報告に関する誘因整合性条件である。ここで の最適契約問題は, 契約の経済理論におけるモラル ハザードモデルの一種であるが, 代表的な教科書 ${ }^{5)-9)}$ 
で最初に取り上げられる標準的なモデルと比べて次 の二点で異なっている. 第一は, 標準的なモデルで は一種類のリスクしか想定されないのに対し，上述 の問題では分析を通じて得られる情報に関するリス クと事後的に実現する状態に関するリスクの二種類 が想定されている点である. 第二は, 標準的なモデ ルでは一種類の誘引整合性条件しか考慮されないの に対し，上述の問題では分析結果の正直な報告に関 する誘因整合性条件を含む二種類の誘引整合性条件 が考慮されている点である.

上述の最適契約問題を解くことでリスク負担制度 を有効に機能させる報酬が導出されるのだが，先行 研究 ${ }^{4)}$ では最適契約問題の解になる報酬が情報価値

（VOI : Value of Information）に基づく報酬

$$
\omega_{V O I}(a \mid \theta, d) \equiv r B\left(p^{*}(\theta, d), a\right)+s
$$

もしくは対数スコア（logS : logarithmic Score）に基 づく報酬

$$
\omega_{\log S}(a \mid \theta, d) \equiv r \log q(a \mid \theta, d)+s
$$

のいずれかで表される必要があることが明らかにさ れている.ただし, $r$ と $s$ はパラメータ, $q(a \mid \theta, d)$ は 水準 $\theta$ の分析で情報 $d$ を得た場合における状態 $a$ の 予測確率である. 前者では, 事後的に支払われる報 酬が事後的に実現する社会的純便益に比例しており， 後者では, 事後的に実現する状態についての事前予 測確率の対数に比例している. 両方の報酬において, パラメータ $r$ が変動部分の大きさに, パラメータ $s$ が固定部分の大きさに関係している. 式(21)-(24)の 最適化問題に式(25)または式(26)を代入して最適解 を求めることで, 分析水準 $\theta$ とパラメータ $r, s$ が具 体的に求められる，例えば, 式(26)を代入した場合 には,

$$
\begin{aligned}
& \theta_{\log S}^{R S} \equiv \arg \max _{\theta \in[0.1 / \kappa]}\left[E S N B^{*}(\theta)\right.-\frac{1+\kappa \theta}{2} \varphi\left\{A\left(\log \frac{1+\kappa \theta}{2}-S(\theta) \frac{\theta^{2}}{\kappa}+B\right\}\right. \\
&\left.-\frac{1-\kappa \theta}{2} \varphi\left\{A\left(\log \frac{1-\kappa \theta}{2}-S(\theta)\right) \frac{\theta^{2}}{\kappa}+B\right\}\right] \\
& r_{\log S}^{R S} \equiv \frac{6 c}{\log \left(1+\kappa \theta_{\log S}^{R S}\right)-\log \left(1-\kappa \theta_{\log S}^{R S}\right)} \frac{\left(\theta_{\log S}^{R S}\right)^{2}}{\kappa} \\
& s_{\log S}^{R S} \equiv \underline{U}+c\left(\theta_{\log S}^{R S}\right)^{3}-r_{\log S}^{R S} S\left(\theta_{\log S}^{R S}\right)
\end{aligned}
$$

と求められる (先行研究 ${ }^{3)}$ を参照).ただし, $S(\theta)$, $A, B$ は次のとおり定義される変数である.

$$
\begin{aligned}
& S(\theta) \equiv \frac{1+\kappa \theta}{2} \log \frac{1+\kappa \theta}{2}+\frac{1-\kappa \theta}{2} \log \frac{1-\kappa \theta}{2} \\
& A=\frac{6 c}{\log (1+\kappa \theta)-\log (1-\kappa \theta)} \\
& B=\underline{U}+c \theta^{3}
\end{aligned}
$$

\section{（2）リスク負担制度の性質}

リスク負担制度の性質を検討することで次の 4 点 が確認される．第一は，式(28)で与えられるパラメ 一タが非零の值をとり, 危険回避的な分析者がリス クの一部を負担するため, 危険中立的な計画主体が 全てのリスクを負担する対称情報の場合よりも低い 期待社会的厚生が実現することである．第二は，式 (22)に式(25),(28)-(29)を代入することで確認される とおり, 分析者が対称情報下の場合と同様に留保効 用水準を享受することである．第三は，式(27)で与 えられる分析水準が式(18)で与えられる対称情報の 場合における分析水準と比較して高くなるか低くな るかは不明な点である．第四は，第一と第二の点か ら導かれるとおり, 分析者が得る事後的な報酬が負 になる確率が常に正になることである．第一点から 第三点はマニピュレーション抑止制度の効率性に関 わる視点であり，第四点は社会的受容性に関わる視 点である. リスク負担制度以外のマニピュレーショ ン抑止制度を検討する際にも，ここで指摘した 4 点 について検討していくことが有益であると考えられ る.

\section{(3) 分析の留意点}

リスク負担制度の導出にあたり, 次のような前提 条件が置かれていた。

(1)分析者の報酬の大きさに制約はない.

(2)一人の分析者と契約が結ばれる.

(3)一回限りの契約が結ばれる.

(4)再交渉が認められない契約が結ばれる.

(5)国民は分析水準と分析で得られる情報を決して 知ることはできない.

当然のことながら，それぞれの前提条件を緩和すれ ば，リスク負担制度とは異なる制度を想定すること が可能になる．例えば，(2)を緩和することで複数の 分析者の相対評価を利用した制度が, (3)を緩和する ことで取引きが繰り返し行われる状況を利用した制 度が思い浮かんでくる．4. 以降では(1)から(5)の前 提条件を緩和しながら，リスク負担制度とは異なる マニピュレーション抑止制度の代替案を一つずつ定 義し, それぞれの理論的性質を検討していく.

\section{4. 有限責任制度}

\section{(1) 着眼点}

リスク負担制度のもとでは, 分析者が事後的に得 る報酬が負になる可能性が常に存在する. しかし， 社会基盤施設整備の需要予測をめぐる現行の経済慣 行を見渡すかぎり，予測が外れたからとの理由で分 析者にパナルティを課すような制度が社会的に受け 入れられるとは考えにくい. 何らかの形でペナルテ イを課すことがあるとしても，ペナルティの大きさ 
は法的ルールなどで一定水準以下に制約されると考 えられる，契約の経済理論では，報酬が一定額以上 でなければならないとする制約は有限責任制約（ま たは破産制約）と呼ばれており，有限責任制約が課 されたモラルハザード問題についての研究も進んで いる ${ }^{13), 14)}$. 本節では, 分析者の有限責任を考慮した マニピュレーション抑止制度（以下，有限責任制度 と呼ぶ）について検討する.

\section{（2）有限責任制度の契約}

有限責任制度では, リスク負担制度と同様に, 分 析者に予测に起因するリスクの一部を負担させるこ とで, 分析者に質の高い分析を行うインセンティブ と分析結果を正直に報告するインセンティブが与え られる，有限責任制度を有効に機能させる報酬は， リスク負担制度の定義に用いられた式(21)-(24)の最 適化問題に有限責任制約

$$
\omega(a \mid \theta, d) \geq-L \quad \forall d \in\{\underline{d}, \bar{d}\},{ }^{\forall} a \in[\underline{a}, \bar{a}]
$$

（ただし， $L \geq 0$ はパラメータ）を追加した最適化問 題の解として定義される. 有限責任制度を機能させ る報酬も式(25)もしくは式(26)の形で表されなけれ ばならず，式(21)-(24),(33)の最適化問題にいずれか を代入して最適解を求めることで, 分析水準 $\theta$ とパ ラメータ $r, s$ が具体的に求められる. 報酬が式(26) の形で表される場合，リスク負担制度のもとでの報 酬と分析水準が有限責任制約

$$
r_{\log S}^{R S} \log \frac{1-\kappa \theta_{\log S}^{R S}}{2}+s_{\log S}^{R S} \geq-L
$$

を満たすならば，有限責任制度のもとでの報酬と分 析水準はリスク負担制度のもとでのそれらと等しく なる。一方, リスク負担制度のもとでの報酬と分析 水準が有限責任制約を満たさないならば，有限責任 制度のもとでの報酬と分析水準は

$$
\begin{aligned}
& \left(\theta_{\log S}^{L L}, s_{\log S}^{L L}\right) \\
& =\arg \max _{\theta \in[0,1 / \kappa], s}\left[\operatorname{ESNB}^{*}(\theta)\right. \\
& -\frac{1+\kappa \theta}{2} \varphi\left\{A \frac{\theta^{2}}{\kappa} \log \frac{1+\kappa \theta}{2}+s_{\log s}^{L L}\right\} \\
& \left.-\frac{1-\kappa \theta}{2} \varphi\left\{A \frac{\theta^{2}}{\kappa} \log \frac{1-\kappa \theta}{2}+s_{\log s}^{L L}\right\}\right] \\
& \text { s.t. } A \frac{\theta^{2}}{\kappa} \log \frac{1-\kappa \theta}{2}+s \geq-L \\
& r_{\log S}^{L L} \equiv \frac{6 c}{\log \left(1+\kappa \theta_{\log S}^{L L}\right)-\log \left(1-\kappa \theta_{\log S}^{L L}\right)} \frac{\left(\theta_{\log S}^{L L}\right)^{2}}{\kappa}
\end{aligned}
$$

\begin{tabular}{|c|c|c|c|c|c|}
\hline & \multicolumn{4}{|c|}{ 分析者 2} \\
\hline & & $\underline{a}, \bar{d}_{2}$ & $\underline{a}, d_{2}$ & $\bar{a}, \bar{d}_{2}$ & $\bar{a}, \underline{d}_{2}$ \\
\hline \multirow{4}{*}{$\begin{array}{l}\text { 分 } \\
\text { 析 } \\
\text { 者 } \\
1\end{array}$} & $\underline{a}, \bar{d}_{1}$ & $\frac{\left(1-\kappa \theta_{1}\right)\left(1-\kappa \theta_{2}\right)}{8}$ & $\frac{\left(1-\kappa \theta_{1}\right)\left(1+\kappa \theta_{2}\right)}{8}$ & 0 & 0 \\
\hline & $\underline{a}, d_{3}$ & $\frac{\left(1+\kappa \theta_{1}\right)\left(1-\kappa \theta_{2}\right)}{8}$ & $\frac{\left(1+\kappa \theta_{1}\right)\left(1+\kappa \theta_{2}\right)}{8}$ & 0 & 0 \\
\hline & $\bar{a}, \bar{d}_{1}$ & 0 & 0 & $\frac{\left(1+\kappa \theta_{1}\right)\left(1+\kappa \theta_{2}\right)}{8}$ & $\frac{\left(1+\kappa \theta_{1}\right)\left(1-\kappa \theta_{2}\right)}{8}$ \\
\hline & $\bar{a}, \underline{d}_{1}$ & 0 & 0 & $\frac{\left(1-\kappa \theta_{1}\right)\left(1+\kappa \theta_{2}\right)}{8}$ & $\frac{\left(1-\kappa \theta_{1}\right)\left(1-\kappa \theta_{2}\right)}{8}$ \\
\hline
\end{tabular}

と特徵づけられる（導出過程は式(27)-(29)とほぼ同 じであるので省略）。
表-2 同時生起確率

\section{（3）有限責任制度の性質}

有限責任制約が非拘束的な場合（式(34)が㛜密な 不等号で成立する場合），有限責任制度はリスク負 担制度と全く異ならない。一方，有限責任制約が拘 束的な場合（式(34)が等号で成立する場合）に有限 責任制度が満たす性質を検討することで，次の 4 点 が確認される。第一は，有限責任制度が有限責任制 約が新たに追加された最適化問題の解として定義さ れているため, リスク負担制度よりも低い期待社会 的厚生しか達成できないことである．第二は，簡単 な計算で確認できるのだが，分析者がリスク負担制 度の場合とは異なり, 留保効用を上回る期待効用を 享受することである．第三は，分析水準がリスク負 担制度の場合よりも必ず小さくなることである（ 式(27), (29),(35)）. 第四は, $L=0$ になれば, 分析者 が得る事後的な報酬が常に非負になることである. 有限責任制度は, 分析者が事後的に大きなペナルテ イを課されることがなくなるため, 社会的受容性も リスク負担制度より高いと予想される.ただし, 分 析者に分析水準向上のインセンティブを与えるコス トも大きく，結果として，国民が達成する期待社会 的厚生もリスク負担制度のそれよりも低くなってし まっている.

\section{5.トーナメント制度}

\section{(1) 着眼点}

社会基盤施設整備の場合，事業実施後の施設供用 水準（施設利用者数など）は景気変動という複数の プロジェクトに共通したリスクの影響を受けやすい. 景気変動は事前の需要予測に大きなリスクをもたら す要因の一つであり, 個々の予測業務ごとに契約が 結ばれるリスク負担制度のもとでは，危険回避的な 分析者に景気変動に起因するリスクの一部が課され ることになる。しかし, 個々の分析者にマクロ経済 の景気変動リスクを負担させることが効率的である かというと疑わしい点もある. 複数の事業に共通し て生じるリスクについては, 分析者の需要予測のパ フォーマンスを相対的に評価することで取り除ける 可能性がある. 契約の経済理論では, 相対評価に基 
づいたインセンティブ・メカニズムはランク・オー ダー・トーナメントとして知られている ${ }^{15), 16)}$. 本節 ではランク・オーダー・トーナメントのアイディア に基づいたマニピュレーション抑止制度（以下，卜 ーナメント制度と呼ぶ）について検討する。

\section{(2) モデル}

トーナメント制度を導出するには，2．で定義し た道路投資・需要予測問題を若干修正する必要があ る.ここでは $2 つ の$ 社会基盤施設整備事業が同時に 実施されている状況を想定する.

国民は 2 つの社会基盤施設整備事業から得られる 期待社会的純便益の和の最大化を望んでいるものと する. 国民は $2 つ の$ 事業の需要予測を 2 人の分析者 に別々に委託するものとする. 分析者による需要予 測問題は基本的に2. と同じであるが，事業実施の 結果として実現するパラメータ $a$ は 2 つ事業間で 完全に相関しているものとする. 2 人の分析者を分 析者 1 および分析者 2 とし，それぞれが得る情報を $d_{1}$ および $d_{2}$ で表す. パラメータと情報の同時生起確 率が表-1 で表されるとおりであると仮定すると, $\left(a, d_{1}, d_{2}\right)$ の同時生起確率は表-2 に示されるとおり 表される.

\section{（3）トーナメント制度の契約}

それぞれの分析者は，国民と同様，他の分析者が 選択した分析水準と分析を通じて得た情報を知るこ とができないものとする．ここで，国民が以下の 4 つのステップから成る契約を二人の分析者に提示す る状況を考えてみる.

Step1: 国民は分析者 $i \in\{1,2\}$ に水準 $\tilde{\theta}_{i} \in[0,1 / \kappa]$ の分 析を実施することを要求し, 分析者 $i$ は水準 $\theta_{i}$ の分析を実施する.

Step2：国民は分析者 $i$ に対して分析で得た情報 $\tilde{d}_{i} \in\left\{\tilde{d}_{i}, \tilde{\bar{d}}_{i}\right\}$ と予測結果 $\tilde{q}_{i}\left(a \mid \tilde{\theta}_{i}, \tilde{d}_{i}\right)$ を報告さ せる. ただし, $\tilde{d}_{i}, \tilde{\theta}_{i}, \tilde{q}_{i}\left(a \mid \tilde{\theta}_{i}, \tilde{d}_{i}\right)$ は分析者 が国民に対して報告する情報, 分析水準, 予 測結果（パラメータ $a$ に関する条件付き確 率）であり，分析を通じて得た真の情報 $d_{i}$, 実際に選択した分析水準 $\theta_{i}$, 分析を通じて得 た真の予測結果 $q_{i}\left(a \mid \theta_{i}, d_{i}\right)$ と一致している とは限らない.

Step3 : 国民は分析者 $i$ からの報告に基づいて事業の 投資水準を $p\left(\tilde{\theta}_{i}, \tilde{d}_{i}\right)$ に決定する.

Step4 : 事後的にパラメータ $a$ が観測された状況にお いて, 分析者から報告された情報 $\tilde{d}_{i}$ と予測結 果 $\tilde{q}_{i}\left(a \mid \tilde{\theta}_{i}, \tilde{d}_{i}\right)$ が表-2 から導出される事後確 率と整合しており, $\tilde{q}_{i}\left(a \mid \tilde{\theta}_{i}, \tilde{d}_{i}\right) \geq \tilde{q}_{j}\left(a \mid \tilde{\theta}_{j}, \tilde{d}_{j}\right)$
を満たすならば，国民は分析者 $i$ に対して報 酬 $\omega^{H}=\varphi\left(u^{H}\right)$ を支払い, それ以外の場合には 報酬 $\omega^{L}=\varphi\left(u^{L}\right)$ を支払う.ただし, $u^{H}$ と $u^{L}$ は $u^{H} \geq u^{L}$ を満たす.

以上の契約を本稿ではトーナメント制度と呼ぶ。 Step4 における報酬の定義からわかるとおり, 事後的 に実現した状態に付与した事前予測確率の大小の相 対評価に分析者への報酬を連動させている点に特徴 がある。

トーナメント制度のもとでの分析者の最適戦略に ついて分析すると, 分析水準の選択および分析結果 の報告に関する最適戦略のナッシュ均衡解が

$$
\begin{aligned}
& \theta_{i}=\theta_{j}=\left\{\begin{array}{cl}
1 & \text { if } \frac{4 c}{\kappa^{2}} \leq u^{H}-u^{L} \\
\frac{\kappa\left(u^{H}-u^{L}\right)}{8 c-\kappa^{2}\left(u^{H}-u^{L}\right)} & \text { if } 0 \leq u^{H}-u^{L} \leq \frac{4 c}{\kappa^{2}}
\end{array}\right. \\
& \tilde{q}_{i}\left(a \mid \tilde{\theta}_{i}, \bar{d}_{i}\right)=\tilde{q}_{j}\left(a \mid \tilde{\theta}_{j}, \bar{d}_{j}\right) \\
& \tilde{q}_{i}\left(a \mid \tilde{\theta}_{i}, \underline{d}_{j}\right)=\tilde{q}_{j}\left(a \mid \tilde{\theta}_{j}, \underline{d}_{j}\right)
\end{aligned}
$$

と特徴づけられることが確認される（付録参照）。 式(38)-(39)を満たす予測結果の報告の組み合わせは 無数に存在する. 二人の分析者が真の予測結果を報 告するのも式(38)-(39)を満たす組み合わせの一つで あるが，それが実現するとは必ずしも限らない．た だし，それぞれの分析者が相手の報告内容を事前に 知り得ない状況では, 無数に存在する予測結果の報 告に関するナッシュ均衡解のうち, 両者が真の予測 結果を報告するナッシュ均衡解が自然と選ばれる可 能性は相対的に高いと推測することも可能である.

本稿では，二人の分析者と国民がそうした推測を行 うものと仮定する.

以上の準備のもと, 表-2 に示される同時生起確率, 報酬の定義式および式(37)-(39)の分析者の最適戦略 のナッシュ均衡解に注意すると, トーナメント制度 のもとでの最適な分析水準と報酬を次の最適化問題 の解として定義することができる.

$\max _{u^{H}, u^{m}, \theta \in[0,1 / \kappa]} 2\left[\operatorname{ESNB}^{*}(\theta)-\frac{3+\kappa^{2} \theta^{2}}{4} \varphi\left(u^{H}\right)-\frac{1-\kappa^{2} \theta^{2}}{4} \varphi\left(u^{L}\right)\right]$

s.t.

$$
\begin{aligned}
& \theta=\left\{\begin{array}{cc}
\frac{1}{\kappa} \quad \text { if } \frac{4 c}{\kappa^{2}} \leq u^{H}-u^{L} \\
\frac{\kappa\left(u^{H}-u^{L}\right)}{8 c-\kappa^{2}\left(u^{H}-u^{L}\right)} \text { if } 0 \leq u^{H}-u^{L} \leq \frac{4 c}{\kappa^{2}}
\end{array}\right. \\
& \frac{3+\kappa^{2} \theta^{2}}{4} u^{H}-\frac{1-\kappa^{2} \theta^{2}}{4} u^{L}-C_{s}(\theta) \geq \underline{U} \\
& u^{H} \geq u^{L}
\end{aligned}
$$

式(41)は分析者が選択する分析水準, 式(42)は分析者 の参加制約条件である. 式(40)は目的関数であり, [ ] 
内の第二項はそれぞれの分析者に対して $\left(3+\kappa^{2} \theta^{2}\right) / 4$ の確率で報酬 $\omega^{H}$ が支払われることを， 第三項は $\left(1-\kappa^{2} \theta^{2}\right) / 4$ の確率で報酬 $\omega^{L}$ が支払われる ことを表している.確率 $\left(3+\kappa^{2} \theta^{2}\right) / 4$ は両方の分析者 に共通の情報を得て同一の予測結果を報告する確率 $\left(1+\kappa^{2} \theta^{2}\right) / 2$ と異なる情報を得て相対的に高い予測 確率を付与した状態が実現する確率 $\left(1-\kappa^{2} \theta^{2}\right) / 4$ の 和であり，確率 $\left(1-\kappa^{2} \theta^{2}\right) / 4$ は異なる情報を得て相対 的に低い予測確率を付与した状態が実現する確率で ある。

\section{（4）トーナメント制度の性質}

式(40)-(43)の最適化問題を解くことでトーナメン 卜制度が具体的に求められる. 解析的に解くことは 困難であるが，トーナメント制度の性質として次の 3 点を確認することはできる. 第一は, 分析者によ る分析水準の選択に影響するのが 2 つの報酬の差で あり, 報酬の水準ではないため, 計画主体には報酬 の水準を下げるインセンティブが働き, 分析者の期 待効用が留保効用水準に等しくなることである. 第 二は, $\theta<1 / \kappa$ の場合, 分析者が予測リスクの一部を 負担するため国民の期待社会的厚生が対称情報下の 場合より低くなることである. 第三は, $\theta=1 / \kappa$ の場 合, 二人の分析者が常に共通の情報を得て同一の予 測結果を報告するため, 予測結果のパフォーマンス を相対評価するトーナメント制度のもとでは結果的 に分析者が予測リスクを一切負担しなくなり, 対称 情報下の場合と同じ期待社会的厚生が達成されるこ とである.

以上の指摘のうち, 特に興味深いのは第二点およ び第三点である. ランク・オーダー・トーナメント に関する既存研究から, 複数の代理人が遂行する業 務のリスクが完全相関している場合には, 最適契約 のもとでファーストベスト解を達成可能なことが明 らかにされている. しかし, 本稿で取り扱う需要予 測問題では 2 種類のリスクの存在を考慮しなければ ならない. 本節の分析では, パラメータ $a$ の実現に 関するリスクこそ完全相関していたものの, 分析を 通じて得られる情報に関するリスクは独立していた． その結果, 後者のリスクが消失する $\theta=1 / \kappa$ の場合を 除いてファーストベスト解が達成されないとの分析 結果が得られた. リスク負担制度のもとでは, 最適 分析水準が $\theta=1 / \kappa$ になる場合であっても分析を通 じて得る情報に関して分析者は常に一定のリスクに 直面せざるを得なかったため, ファーストベスト解 は決して達成されなかった。この点を踏まえると, トーナメント制度は期待された程には有効でないも のの, ある状況（精度の高い予測作業が行われる状 況など）においては，リスク負担制度と比較して一 定の有效性を兼韹えているということができる。

\section{6. 繰り返し取引き制度}

\section{(1) 着眼点}

社会基盤施設整備の需要予測には一定のノウハウ が必要であり, 予測業務の経験を有する分析者は繰 り返し業務に携わっている. 予測業務の発注者は, 個々の需要予測のパフォーマンスに応じて報酬を変 化させるといったことはせず，当該分析者が過去に 実施した需要予測のパフォーマンスを総合的に勘酌 して当該分析者に新たな業務を発注するかどうかの 意思決定を行っていると見ることができる.

以上の想定は, 国民と分析者の間で繰り返しゲー ムが行われている状況とみなすことができる. ゲー 厶理論の既存研究において, 取引きが一回限りで行 われる状況から繰り返し行われる状況一と変化する ことで, 効率性を達成する可能性が著しく大きくな ることが知られている ${ }^{17)}$. 本節では予測業務をめぐ る取引きが繰り返し行われる状況を想定し, そのも とでのマニピュレーション抑止制度 (以下, 繰り返 し取引き制度と呼ぶ）について検討する。

\section{(2) モデル}

繰り返し取引き制度を導出するため，2，で定義 した道路投資・需要予測問題を若干修正する.ここ では，ある時点において，2. で提示された社会基 盤施設整備事業が同時に $\mathrm{n}$ 個実施されるものとする. 国民は期待社会的純便益の最大化を目的として一人 の分析者に全ての需要予測を委託するものとする. 分析者は各事業毎に水準 $\theta_{i}$ の分析を行って情報 $d_{i}$

（ただし， $i \in\{1, \cdots, n\})$ を得てから, 予測結果 $q_{i}\left(a_{i} \mid \theta_{i}, d_{i}\right)$ を報告する. 情報 $d_{i}$ とパラメータ $a_{i}$ の同 時生起確率は表-1 のとおりであり, それぞれの事業 毎に独立しているものとする. 第 $t+1$ 期の期首に第 $t$ 期に実施された全ての事業について実現したパラ メータ $a$ が明らかになるものとする. 分析者は時間 選好率 $\delta$ を有しており, 各期に享受する効用の割引 現在価值を目的関数として行動するものと仮定する.

\section{（3）繰り返し取引き制度の契約}

ここで，国民と分析者の間で次の 4 つのステップ からなる繰り返しゲームが行われる状況を想定する.

Step 1 : 国民は, 分析者に対して一事業ごとに定額報 酬 $\omega$ を支払って需要予測を委託する. 委託に 際して, 全ての事業に共通する分析水準 $\tilde{\theta}$ 指定する. 分析者は事業毎に水準 $\theta_{i}$ の分析を 実施して情報 $d_{i}$ を得る.

Step2 : 国民は分析者に対して分析を通じて得た情報 $\tilde{d}$, ならびにパラメータ $a$ についての予測結 果 $\tilde{q}_{i}\left(a_{i} \mid \tilde{\theta}, \tilde{d}_{i}\right)$ を報告させる.

Step3 : 国民は分析者からの報告結果に基づいて各事 
業の投資水淮を $p\left(\tilde{\theta}_{i}, \tilde{d}_{i}\right)$ に決定する.

Step4 : 第 $t+1$ 期に第 $t$ 期に実施された全事業の平均 便益が計測される．社会的純便益の平均值が トリガー条件

$$
\left|\operatorname{ESBN}(\tilde{\theta})-\frac{\sum_{i \in\{1, \cdots, n\}}\left[\begin{array}{l}
B\left(p^{*}\left(\tilde{\theta}_{i}, \tilde{d}_{i}\right), a_{i}\right) \\
-C_{I}\left(p^{*}\left(\tilde{\theta}_{i}, \tilde{d}_{i}\right)\right)
\end{array}\right]}{n}\right|<T r
$$

（ただし， $T r>0$ はパラメータ）を満たす場 合，第 $t+1$ 期に実施する事業についても第 $t$ 期と同じ分析者に予想業務を再度委託する. 一方，トリガー条件が満たされない場合には 別の分析者に委託する.

以上の暗默の契約を本稿では繰り返し取引き制度 と呼ぶ. 繰り返し取引き制度は次の最適化問題の解 として定義される.

$$
\begin{aligned}
& \max _{\theta \in[0,1 / \kappa], \omega, T r} n\left[E S N B^{*}(\theta)-\omega\right] \\
& \text { s.t. } \\
& u(n \omega)-n C_{s}(\theta) \geq \underline{U} \\
& n\left(C_{s}(\theta)-C_{s}(0)\right)+\frac{\delta \underline{U}}{1-\delta}<\frac{P_{T r} \delta\left(u(n \omega)-n C_{s}(\theta)\right)}{1-P_{T r} \delta}
\end{aligned}
$$

ただし， $P_{r r}$ は式(44)のトリガー条件が満たされる確 率である. 式(46)は分析者の参加制約条件，式(47)は 分析水準の選択に関する誘引整合性条件である，左 辺は分析水準を低减させることで生じる分析費用の 節約分と第 $t+1$ 期以降に達成する留保効用水準の割 引現在価值であり，右辺は分析水準を低減させない 場合に第 $t+1$ 期以降に達成する効用水準の割引現在 価値である.

\section{（4）繰り返し取引き制度の性質}

式(45)-(47)の最適化問題を解くことで繰り返し取 引き制度が具体的に導出される. 繰り返し取引き制 度の性質を検討することで次の 5 点が確認される. 第一に, 分析者の参加制約条件が不等号で満たされ なければならず，分析者が留保効用水準以上の効用 を常に享受することである（ $\because$ 式(46)-(47)）。第二 に, 参加制約条件が厳密に不等式で成立するため, 国民の期待社会的厚生がファーストベスト解よりも 必ず低くなることである，第三に，各時点で実施さ れるプロジェクト数が無限大に近づくと大数の法則 より任意の正のパラメータ $T r$ にいてトリガー条 件が満たされることである，第四に，簡単な計算で 確認できるのだが，分析者の時間選好率が十分に 1 に近く, プロジェクト数が十分に大きい場合, 国民 が享受する期待社会的厚生がファーストベスト解に 収束することである，第五に，リスク負担制度やト
一ナメント制度とは異なり，分析者に対する報酬が 予測結果の当否によって変動せず, しかも予測作業 を行う前に確定することである.

以上の指摘のうち, 特に興味深いのは第三点と第 四点である. 本稿の分析枠組みでは，ある時点で事 前の需要予測と事後的に実現した状態の乘離が見ら れたとしても，それが分析者の不適切な行動（不十 分な分析水準および不正直な報告）に起因するもの なのか，それとも偶然に起因するものなのかを分析 者以外が確認することはできない，繰り返し取引き 制度では，十分な数の事業を集計して平均值を用い ることで, 偶然に起因する要因の影響を取り除くこ とが試みられている。なお，上述のトリガー条件は 一定の確率で誤った判断を下すとの意味で誤差を含 んでいる．誤差を含むモニタリングが効率性の達成 に寄与しうるかどうかについては異論もあり得よう が，この点については，繰り返しゲーム理論の分野 で展開されてきた不完全な公的モニタリングの意義 に関する研究 ${ }^{18)}$ を参照されたい.

\section{7. 再交渉制度}

\section{（1）着眼点}

社会基盤施設整備の場合, 需要予測を行ってから 施設供用後の施設利用水準が明らかになるまで相当 な長期間を要することが少なくない，需要予測の分 析結果の報告後に分析内容が適切であるかどうかを 確認する作業が行われる可能性があると考えられる. この時, 事前にリスク負担制度が採用されていたと しても，分析内容を確認する段階において国民と分 析者の間で事前の契約内容を見直すインセンティブ が生じる可能性がありうる.

以上の想定は契約の経済理論では再交渉がある状 況での最適契約問題として知られている。 モラルハ ザードモデルでは，再交渉が行われる段階でプリン シパルが契約締結段階よりも十分な情報を獲得して いるならば，プリンシパルが享受する効用水準が増 加してファーストベスト解を達成できる可能性があ ることが知られている ${ }^{19)}$. 本節では，事後的な再交 渉が行われる状況を想定して，その枠組みのもとで のマニピュレーション抑止制度（以下，再交涉制度 と呼ぶ）について検討する.

\section{（2）再交渉制度の契約}

ある時点において，2．で提示された社会基盤施 設整備事業が 1 つだけ実施される状況を想定する. 国民は期待社会的純便益の最大化を目的として分析 者に需要予測を委託する. 国民は分析者から予測結 果が報告された段階において分析内容を確認し，分 析者に対して再契約を提示することができるものと 仮定する。 
以上の準備のもと，国民から分析者に対して次の 4 つのステップからなる状況を想定する.

Step1: 国民は分析者に対してリスク負担制度に基づ く契約を提示する.

Step2 : 分析者は分析を実施し, 分析を通じて得た情 報と需要予測の分析結果を国民に報告する.

Step3 : 国民は分析者からの報告結果に基づいて各事 業の投資水準を決定する.

Step4 : 国民は分析内容を確認した後に, 分析者に対 してリスク負担制度で定められた報酬から定 額報酬

$$
\bar{\omega}(d) \equiv \varphi\left(E_{a}[u(\omega(a \mid \theta, d)) \mid \theta, d]\right)
$$

への変更を再契約として提示する.

以上の契約の流れを本稿では再交渉制度と呼ぶ. 式(48)で表される定額報酬の定義式をリスク負担制 度における誘因整合性条件（式(23)-(24)）に代入し ても符号を変化させないことが確認される。また， 参加制約条件（式(22)）に代入すると参加制約条件 を等号で成立させることが確認される，一方，目的 関数（式(21)）に代入すると分析者への報酬の期待 支払額を減少させることで期待社会的厚生を増加さ せることが確認される，結局，式(48)の定額報酬に 基づく再交渉は, リスク負担制度のもとでの分析者 のインセンティブを損なわずに，国民が最終的に享 受する期待社会的厚生を増加させる.

\section{（3）再交渉制度の性質}

再交渉制度の性質として次の 4 点が確認される. 第一は, リスク負担制度と同じく, 分析者の期待効 用が留保効用水準に等しくなることである.第二は,

（2）で指摘したとおり，国民の期待社会的厚生が リスク負担制度の場合よりも常に増加することであ る. 第三は，分析者は将来実現する状態に関するリ スクは負担しないものの, 分析で得られる情報に関 するリスクを依然として負担するため, ファースト ベスト解は依然として達成されないことである。第 四は, 分析者が最終的に達成する効用水淮が, 将来 実現する状態が判明する前の段階で確定することで ある。

以上の指摘のうち, 特に興味深いのは第四点であ る. リスク負担制度の導入を難しくする要因の一つ に，分析者に対する報酬が将来時点の判明後にしか 確定しないという点がある. 将来時点が判明するま でに長期間を要する場合, 精度の低い予測結果を報 告した分析者に事後的なペナルティを課すことは現 実的に難しくなるといわざるを得ない，再交涉制度 は，期待社会的厚生の観点でリスク負担制度より望 ましいだけでなく, 制度の導入可能性という観点で もリスク負担制度より望ましいといえる。

\section{8. 監査制度}

\section{(1) 着眼点}

需要予測の分析内容や分析手順を分析者以外の人 間が理解することは一般に困難である. 本稿では, そうした理解のもと, 分析者が選択した分析水準や 分析を通じて得た情報を国民が知ることはできない とこれまで仮定してきた．しかし，現実には国民が 一定の費用を負担して監査を実施することで，分析 者が誤った分析内容を報告したり，誤った分析手順 を採用していないか確認することができるかもしれ ない，そして，分析者の虚偽報告に対してペナルテ イを課すことを制度化することで，分析者によるマ ニピュレーションを未然に防ぐことができるかもし れない、本節では, 事後的な監查が行われる状況を 想定して, その枠組みのもとでのマニピュレーショ ン抑止制度（以下，監查制度と呼ぶ）について検討 する。

\section{（2）監査制度の契約}

ある時点において，2．で提示された社会基盤施 設整備事業が 1 つだけ実施される状況を想定する. 国民は分析者に需要予測を委託するのだが，分析者 から予測結果が報告された段階において，監查機関 に分析者が真の分析結果を報告したかどうかの監査 を委託するものとする. 分析者が偽りの分析結果を 報告してきた場合に監查機関がそれを発見する確率 が $f \in[0,1]$ で表され，発見確率 $f$ の監查の実施に監 査機関が要する費用関数が $C_{A}(f)$ で表されるものと する（ただし， $\left.C_{A}(0)=0, C_{A}^{\prime} \geq 0, C_{A}^{\prime \prime}>0\right)$. また， 監査機関と分析者は, 監查を通じて分析者が偽りの 予測結果を報告していた事実が発見されたとしても， 結託して事実を隠蔽することはないものとする.

以上の準備のもと，国民から分析者に対して次の 4 つのステップからなる契約が提示される状況を想 定する.

Step 1 : 国民は分析者に対して定額報酬 $\omega$ と分析水準 $\theta$ を指定して予測業務を委託する.

Step2: 分析者は分析を実施し, 分析を通じて得た情 報と需要予測の分析結果を国民に報告する.

Step3 : 国民は分析者からの報告結果に基づいて各事 業の投資水準を決定する.

Step4 : 国民は分析者が分析結果の報告において偽ら なかったかどうか監查機関に調べさせる．分 析者が偽りの分析結果を報告していたことが 監查機関によって発見された場合，国民は分 析者に対してペナルティ $F$ を課す. ペナルテ ^Fの大きさについては, 本稿の分析枠組み 外にある法律等のルールで $0 \leq F \leq \bar{F}$ の範囲 に定められているものとする.また, 監査機 
表-3 マニピュレーション抑止制度の比較

\begin{tabular}{|c|c|c|c|c|c|c|}
\hline & リスク負担制度 & 有限責任制度 & トーナメント制度 & 繰返し取引き制度 & 再交渉制度 & 監査制度 \\
\hline $\begin{array}{c}\text { 期待社会的厚生 } \\
(\text { (劝負担制度との比較) }\end{array}$ & - & $\begin{array}{c}\text { リスク負担制度 } \\
\text { より常に小 }\end{array}$ & $?$ & ? & $\begin{array}{c}\text { リスク負担制度 } \\
\text { より常に大 }\end{array}$ & ? \\
\hline $\begin{array}{l}\text { ファーストベスト } \\
\text { との一致条件 }\end{array}$ & 一致しない & 一致しない. & $\begin{array}{l}\text { 最適分析水隻にて } \\
\text { 情報と将来事象が } \\
\text { 一対一に対応 }\end{array}$ & $\begin{array}{l}\cdot \text { ·各時点の事業数が } \\
\text { 十分に大きい } \\
\text { ·時間選好率が } 1 \text { } \\
\text { 十分に近い }\end{array}$ & 一致しない & 一致しない \\
\hline 分析者の期待効用 & $\begin{array}{l}\text { 留保効用水準 } \\
\text { に一致 }\end{array}$ & $\begin{array}{c}\text { 留保効用水隻 } \\
\text { より大 }\end{array}$ & $\begin{array}{l}\text { 留保効用水漼 } \\
\text { に一致 }\end{array}$ & $\begin{array}{l}\text { 留保効用水隻 } \\
\text { より大 }\end{array}$ & $\begin{array}{l}\text { 留保効用水準 } \\
\text { に一致 }\end{array}$ & $\begin{array}{l}\text { 留保効用水隻 } \\
\text { に一致 }\end{array}$ \\
\hline $\begin{array}{c}\text { 分析者の効用が留保効用 } \\
\text { 水準を下回る可能性 }\end{array}$ & あり & なし & あり & なし & あり & なし \\
\hline $\begin{array}{c}\text { 分析者が負担する } \\
\text { リスク* }\end{array}$ & リスク I+リスク II & リスク I+リスク II & リスク I & リスク I+リスク II & リスク I & なし \\
\hline $\begin{array}{c}\text { 分析者の効用の } \\
\text { 確定段階 }\end{array}$ & 事後状態の判明後 & 事後状態の判明後 & 事後状態の判明後 & 予測業務受託段階 & 予測結果の報告後 & 予測業務受託段階 \\
\hline $\begin{array}{l}\text { 制度を支える前提条件 } \\
\text { (リスク負担制度との比較) }\end{array}$ & - & - & $\begin{array}{l}\text { 類似した事業が } \\
\text { 複数実施される }\end{array}$ & $\begin{array}{l}\text { 複数の事業が } \\
\text { 毎期実施される }\end{array}$ & \begin{tabular}{|l|} 
国民が需要予測の \\
分析内容を確認可能
\end{tabular} & $\begin{array}{l}\text { 虚偽報告を発見する } \\
\text { 監查機関の存在 }\end{array}$ \\
\hline
\end{tabular}

*リスク I : 分析で得られる情報に関するリスク,リスク II：将来実現する状態に関するリスク

関が分析者による虚偽報告を発見したかどう かに関わらず，国民は監査機関が負担した監 查費用を観察して監查機関に対して支払う。

以上の契約を本稿では監查制度と呼ぶ．監查制度を 規定する最適化問題は次のとおり定式化される.

$$
\max _{\theta \in[0,1 / \kappa], \omega, f \in[0,1], F \in[0, \bar{F}]} \operatorname{ESNB}^{*}(\theta)-\omega-C_{A}(f)
$$

s.t.

$$
\begin{aligned}
& \omega-C_{S}(\theta) \geq \underline{U} \\
& \omega-C_{S}(\theta) \geq \omega-C_{S}(0)-f F
\end{aligned}
$$

式(50)は分析者の参加制約条件, 式(51)は分析水準の 選択に関する誘引整合性条件である。予測結果の報 告に関する誘因整合性については，監查制度のもと では明らかに満たされるため, 上述の最適化問題に は現れてこない. 式(49)-(51)の最適化問題を解くこ とで監查制度のもとでの最適解が

$$
\begin{aligned}
& F^{A} \equiv \bar{F} \\
& \left(\theta^{A}, f^{A}\right) \equiv \underset{\theta \in[0,1 / \kappa], f \in[0,1]}{\arg \max }\left[\operatorname{ESNB}^{*}(\theta)-C_{A}(f)\right] \\
& \quad \text { s.t. } f \geq\left(C_{S}(\theta)-C_{S}(0)\right) / F^{A} \\
& \omega^{A} \equiv \underline{U}+C_{S}\left(\theta^{A}\right)
\end{aligned}
$$

と導出される.

\section{（3）監査制度の性質}

監查制度の性質として, 次の 3 点が確認される. 第一は, 分析者の期待効用が留保水準に等しくなる ことである $(\because$ 式(55)) . 第二は, 分析者がリスク を全く負担しないことである $(\because$ 式(55)).第三は, 国民の期待社会的厚生は監查費用の分だけ対称情報 下で得られたそれよりも低下することである，第四 は，計画主体には監查費用を節約するインセンティ ブが働くため，式(52)に示されるとおり，分析者に 対するペナルティが常に上限に等しくなることであ
る. 第五は, 分析者が最終的に達成する効用水準が 予測業務を受託した段階で明らかになることである.

以上の指摘のうち, 特に興味深いのは, 第二点で ある. 分析者が偽りの分析内容を報告してきたかど うか判断できない場合には, リスク負担制度, 有限 責任制度, トーナメント制度, 繰り返し取引き制度, 再交渉制度，のいずれにおいても分析者に何らかの リスクを負担させなければならなかった。しかし， 監查制度のもとでは分析者はリスクを負担する必要 が全くなくなる，予測に起因するリストが非常に大 きく, 監查費用が十分に小さい場合には, 監査制度 が最も有効なマニピュレーション抑止制度になりう ると考えられる.

ただし，監査制度の導入にあたっては，本稿では 想定しなかった分析者と監查機関の間で結ばれる結 託の可能性に注意しなければならない，結託の可能 性が存在する場合には, 監查制度が機能しなくなっ たり，監査制度を機能させるための費用が増大する からである、プロジェクト評価の監査制度をめぐる 研究としては, 筆者らの別の論文 ${ }^{20)}$ 参照されたい.

\section{9. おわりに}

本稿ではマニピュレーション抑止制度として, リ スク負担制度, 有限責任制度, トーナメント制度, 繰り返し取引き制度, 再交涉制度, 監査制度の 6 つ を取り上げた. それぞれの理論的な性質を表-3 に整 理する.

6 つの制度を比較すると, 期待社会的厚生に関し て,「有限責任制度くリスク負担制度<再交渉制度」 という優越関係が成立することが確認される。しか し，その他の制度の組合せについては，いずれが望 ましいか不明である。また，トーナメント制度と繰 り返し取引き制度については, ある条件のもとでフ アーストベストを達成可能なことが確認される，た 
だし、いずれも前提条件が厳密に成立しない場合に， どこまで適用可能性があるかは定かではない.

理論的には，期待社会的厚生を最も大きくするマ ニピュレーション抑止制度が最も望ましいと考えら れるが，現実の制度設計を考えていく際には，制度 の社会的受容性や適用可能性の方がより重要な観点 になる. 分析者が予測に起因するリスクの 2 つを負 担するリスク負担制度や有限責任制度では, 分析者 の効用が確定するのが事後状態の判明後であるうえ， 事後的な効用水準が留保効用水準を下回る可能性が ある. 制度の導入にあたって求められる前提条件が 他の制度と比較して緩いものの，マニピュレーショ ン抑止制度としての有効性は他の制度と比較して相 対的に劣ると考えられる。トーナメント制度も，リ スク負担制度や有限責任制度と同様に, 分析者の効 用が確定するのが事後状態の判明後であり, 事後的 な効用水準が留保効用水準を下回る可能性がある点 で，有効性は低いと判断される。

これに対し, 繰り返し取引き制度, 再交渉制度, 監查制度の 3 つは相対的に有効性が高いと考えられ る.ただし，3つの制度のいずれが望ましいかは， 予測に伴うリスクを平均化して小さくできるだけの 事業が実施されているかどうか, 再交渉に伴う費用 が小さいかどうか，監查に伴う費用が小さいかどう か, 監查費用が小さいかどうか, 監査機関と分析者 の結託を防ぐコストが小さいかどうか，といった実 証的な観点に大きく依存してくるため, 本稿の分析 結果を元にこれ以上の議論を行うことはできない， 今後は, 制度の導入に伴う実証的な困難性をより明 確にすると同時に, 制度の有効性を担保するための 前提条件に対寸る頑健性や事後評価・再評価制度と の補完性を生かした制度設計の可能性などを踏まえ， マニピュレーション抑止制度の制度化に向けてのよ り現実的な政策提言を行っていきたい.

謝辞: 本研究は文部省科学研究費補助金 (課題番号: 15760391）の助成を受けております。ここに記して 感謝の意を表します。

\section{付録 トーナメント制度における分析者の最適応答}

\section{(1) $\tilde{q}_{2}\left(\underline{a} \mid \tilde{\bar{d}}_{2}, \tilde{\theta}_{2}\right)<\tilde{q}_{2}\left(\underline{a} \mid \underline{\tilde{d}}_{2}, \tilde{\theta}_{2}\right)$ の場合}

まず, 分析者 2 の予測結果の報告が $\tilde{q}_{2}\left(\underline{a} \mid \tilde{\bar{d}}_{2}, \tilde{\theta}_{2}\right)$ と $\tilde{q}_{2}\left(\underline{a} \mid \underline{\tilde{d}}_{2}, \tilde{\theta}_{2}\right)$ で表され, $\tilde{q}_{2}\left(\underline{a} \mid \tilde{\bar{d}}_{2}, \tilde{\theta}_{2}\right)<\tilde{q}_{2}\left(\underline{a} \mid \underline{\tilde{d}}_{2}, \tilde{\theta}_{2}\right)$ が 成立する状況について議論を進める. 分析者 1 が水 準 $\theta_{i}$ の分析を実施して情報 $\underline{d}_{i}$ を得たものとする.こ の時, $\tilde{q}_{1}\left(\underline{a} \mid \underline{\tilde{d}}_{1}, \tilde{\theta}_{1}\right)$ と $\tilde{q}_{2}\left(\underline{a} \mid \tilde{\bar{d}}_{2}, \tilde{\theta}_{2}\right)$ および $\tilde{q}_{2}\left(\underline{a} \mid \underline{\tilde{d}}_{2}, \tilde{\theta}_{2}\right)$ の大小関係に応じて次の 5 通りが考えられる.

$$
\text { (1) } 0 \leq \tilde{q}_{1}\left(\underline{a} \mid \underline{\tilde{d}}_{1}, \tilde{\theta}_{1}\right)<\tilde{q}_{2}\left(\underline{a} \mid \tilde{\bar{d}}_{2}, \tilde{\theta}_{2}\right)<\tilde{q}_{2}\left(\underline{a} \mid \underline{\tilde{d}}_{2}, \tilde{\theta}_{2}\right) \leq 1
$$

(2) $0 \leq \tilde{q}_{2}\left(\underline{a} \mid \tilde{\bar{d}}_{2}, \tilde{\theta}_{2}\right)=\tilde{q}_{1}\left(\underline{a} \mid \underline{\tilde{d}}_{1}, \tilde{\theta}_{1}\right)<\tilde{q}_{2}\left(\underline{a} \mid \underline{\tilde{d}}_{2}, \tilde{\theta}_{2}\right) \leq 1$

(3) $0 \leq \tilde{q}_{2}\left(\underline{a} \mid \tilde{\bar{d}}_{2}, \tilde{\theta}_{2}\right)<\tilde{q}_{1}\left(\underline{a} \mid \underline{\tilde{d}}_{1}, \tilde{\theta}_{1}\right)<\tilde{q}_{2}\left(\underline{a} \mid \underline{\tilde{d}}_{2}, \tilde{\theta}_{2}\right) \leq 1$

(4) $0 \leq \tilde{q}_{2}\left(\underline{a} \mid \tilde{\bar{d}}_{2}, \tilde{\theta}_{2}\right)<\tilde{q}_{2}\left(\underline{a} \mid \underline{\tilde{d}}_{2}, \tilde{\theta}_{2}\right)=\tilde{q}_{1}\left(\underline{a} \mid \underline{\tilde{d}}_{1}, \tilde{\theta}_{1}\right) \leq 1$

(5) $0 \leq \tilde{q}_{2}\left(\underline{a} \mid \tilde{\bar{d}}_{2}, \tilde{\theta}_{2}\right)<\tilde{q}_{2}\left(\underline{a} \mid \underline{\tilde{d}}_{2}, \tilde{\theta}_{2}\right)<\tilde{q}_{1}\left(\underline{a} \mid \underline{\tilde{d}}_{1}, \tilde{\theta}_{1}\right) \leq 1$ (1)〜(5)のそれぞれについて, 表-2 に示される同時生 起確率と報酬の定義に注意すると, (4)の場合, すな わち, $\tilde{q}_{1}\left(\underline{a} \mid \underline{\tilde{d}}_{1}, \tilde{\theta}_{1}\right)=\tilde{q}_{2}\left(\underline{a} \mid \underline{\tilde{d}}_{2}, \tilde{\theta}_{2}\right)$ の場合に分析者の期 待効用が最も大きくなり，

$$
\begin{aligned}
& \frac{\left(1-\kappa \theta_{1}\right)\left(1+\kappa \theta_{2}\right)}{4} u^{L}+\frac{\left(1+\kappa \theta_{1}\right)\left(1-\kappa \theta_{2}\right)}{4} u^{H} \\
+ & \frac{\left(1+\kappa \theta_{1}\right)\left(1+\kappa \theta_{2}\right)}{4} u^{H}+\frac{\left(1-\kappa \theta_{1}\right)\left(1-\kappa \theta_{2}\right)}{4} u^{H}-c \theta_{1}^{2}
\end{aligned}
$$

と表されることが確認される. 分析者 1 が $\bar{d}_{i}$ の情報 を得た場合についても $\underline{d}_{i}$ の情報を得た場合と同様 の議論を行うと, $\tilde{q}_{1}\left(\underline{a} \mid \tilde{\bar{d}}_{1}, \tilde{\theta}_{1}\right)=\tilde{q}_{2}\left(\underline{a} \mid \tilde{\bar{d}}_{2}, \tilde{\theta}_{2}\right)$ の場合に 分析者の期待効用が最も大きくなり, 分析者の期待 効用が同じく式(56)で表されることが確認される. 分析者の分析水準に関する選択に関しては, 式(56) の最適化問題の一階条件より, 最適応答関数

$$
\theta_{1}^{*}\left(\theta_{2}\right)=\min \left\{\left(1-\kappa \theta_{2}\right) \kappa\left(u^{H}-u^{l \cdot}\right) / 8 c, 1 / \kappa\right\}
$$

が求められる.

分析者 2 についても同様の議論を行うことで, $\tilde{q}_{2}\left(\underline{a} \mid \tilde{d}_{2}, \tilde{\theta}_{2}\right)=\tilde{q}_{1}\left(\underline{a} \mid \underline{\tilde{d}}_{1}, \tilde{\theta}_{1}\right)$ と $\tilde{q}_{2}\left(\underline{a} \mid \tilde{\bar{d}}_{2}, \tilde{\theta}_{2}\right)=\tilde{q}_{1}\left(\underline{a} \mid \tilde{\bar{d}}_{1}, \tilde{\theta}_{1}\right)$ が満たされる場合に分析者 2 の期待効用が最も大き くなることが確認され, 最適応答関数

$$
\theta_{2}^{*}\left(\theta_{1}\right)=\min \left\{\left(1-\kappa \theta_{1}\right) \kappa\left(u^{H}-u^{L}\right) / 8 c, 1 / \kappa\right\}
$$

が求められる.

以上の議論より，予測結果に関する最適報告が式 (38)-(39)で特徴づけられることが確認される. また, 式(57)と式(58)のナッシュ均衡解を求めることで, 分 析水準の選択に関する最適戦略が式(37)で表される ことが確認される.

\section{(2) $\tilde{q}_{2}\left(\underline{a} \mid \tilde{\bar{d}}_{2}, \tilde{\theta}_{2}\right)>\tilde{q}_{2}\left(\underline{a} \mid \underline{\tilde{d}}_{2}, \tilde{\theta}_{2}\right)$ の場合}

分析者 1 が水準 $\theta_{i}$ の分析を実施して情報 $\underline{d}_{i}$ を得 たものとする.この時, $\tilde{q}_{1}\left(\underline{a} \mid \underline{\tilde{d}}_{1}, \tilde{\theta}_{1}\right)$ と $\tilde{q}_{2}\left(\underline{a} \mid \tilde{\bar{d}}_{2}, \tilde{\theta}_{2}\right)$ お よび $\tilde{q}_{2}\left(\underline{a} \mid \underline{d}_{2}, \tilde{\theta}_{2}\right)$ の大小関係に応じて次の 5 通りが 考えられる.

(6) $0 \leq \tilde{q}_{1}\left(\underline{a} \mid \underline{\tilde{d}}_{1}, \tilde{\theta}_{1}\right)<\tilde{q}_{2}\left(\underline{a} \mid \underline{\tilde{d}}_{2}, \tilde{\theta}_{2}\right)<\tilde{q}_{2}\left(\underline{a} \mid \underline{\bar{d}}_{2}, \tilde{\theta}_{2}\right) \leq 1$

(7) $0 \leq \tilde{q}_{2}\left(\underline{a} \mid \underline{\tilde{d}}_{2}, \tilde{\theta}_{2}\right)=\tilde{q}_{1}\left(\underline{a} \mid \underline{\tilde{d}}_{1}, \tilde{\theta}_{1}\right)<\tilde{q}_{2}\left(\underline{a} \mid \tilde{\bar{d}}_{2}, \tilde{\theta}_{2}\right) \leq 1$

(8) $0 \leq \tilde{q}_{2}\left(\underline{a} \mid \underline{\tilde{d}}_{2}, \tilde{\theta}_{2}\right)<\tilde{q}_{1}\left(\underline{a} \mid \underline{\tilde{d}}_{1}, \tilde{\theta}_{1}\right)<\tilde{q}_{2}\left(\underline{a} \mid \tilde{\bar{d}}_{2}, \tilde{\theta}_{2}\right) \leq 1$

(9) $0 \leq \tilde{q}_{2}\left(\underline{a} \mid \underline{\tilde{d}}_{2}, \tilde{\theta}_{2}\right)<\tilde{q}_{2}\left(\underline{a} \mid \tilde{\bar{d}}_{2}, \tilde{\theta}_{2}\right)=\tilde{q}_{1}\left(\underline{a} \mid \underline{\tilde{d}}_{1}, \tilde{\theta}_{1}\right) \leq 1$

(10) $0 \leq \tilde{q}_{2}\left(\underline{a} \mid \underline{\tilde{d}}_{2}, \tilde{\theta}_{2}\right)<\tilde{q}_{2}\left(\underline{a} \mid \tilde{\bar{d}}_{2}, \tilde{\theta}_{2}\right)<\tilde{q}_{1}\left(\underline{a} \mid \underline{\tilde{d}}_{1}, \tilde{\theta}_{1}\right) \leq 1$

(6)〜10のそれぞれについて, 表-2 に示される同時生 起確率と報酬の定義に注意しながら同様の議論を行 
うと, $\tilde{q}_{1}\left(\underline{a} \mid \tilde{\tilde{d}}_{1}, \tilde{\theta}_{1}\right)=\tilde{q}_{2}\left(\underline{a} \mid \tilde{\bar{d}}_{2}, \tilde{\theta}_{2}\right)$ の場合に分析者の期 待効用が最も大きくなることが確認される. 情報 $\bar{d}_{i}$ を得た場合についても同様の議論を行うと， $\tilde{q}_{1}\left(\underline{a} \mid \tilde{\bar{d}}_{1}, \tilde{\theta}_{1}\right)=\tilde{q}_{2}\left(\underline{a} \mid \underline{\tilde{d}}_{2}, \tilde{\theta}_{2}\right)$ の場合に分析者の期待効 用が最も大きくなることが確認される.この時,

$$
\tilde{q}_{2}\left(\underline{a} \mid \underline{\tilde{d}}_{2}, \tilde{\theta}_{2}\right)=\tilde{q}_{1}\left(\underline{a} \mid \tilde{\bar{d}}_{1}, \tilde{\theta}_{1}\right)<\tilde{q}_{1}\left(\underline{a} \mid \underline{\tilde{d}}_{1}, \tilde{\theta}_{1}\right)=\tilde{q}_{2}\left(\underline{a} \mid \tilde{\bar{d}}_{2}, \tilde{\theta}_{2}\right) \quad \text { (59) }
$$

が成立する.

一方, $\tilde{q}_{1}\left(\underline{a} \mid \tilde{\bar{d}}_{1}, \tilde{\theta}_{1}\right)<\tilde{q}_{1}\left(\underline{a} \mid \underline{\tilde{d}}_{1}, \tilde{\theta}_{1}\right)$ の関係に注意しな がら, 分析者 2 についても同様の議論を行うと, $\tilde{q}_{2}\left(\underline{a} \mid \underline{\tilde{d}}_{2}, \tilde{\theta}_{2}\right)=\tilde{q}_{1}\left(\underline{a} \mid \underline{\tilde{d}}_{1}, \tilde{\theta}_{1}\right)$ と $\tilde{q}_{2}\left(\underline{a} \mid \tilde{\bar{d}}_{2}, \tilde{\theta}_{2}\right)=\tilde{q}_{1}\left(\underline{a} \mid \tilde{\bar{d}}_{1}, \tilde{\theta}_{1}\right)$ の場合に期待効用が最大になることが確認される. この時,

$$
\tilde{q}_{1}\left(\underline{a} \mid \tilde{\bar{d}}_{1}, \tilde{\theta}_{1}\right)=\tilde{q}_{2}\left(\underline{a} \mid \tilde{\bar{d}}_{2}, \tilde{\theta}_{2}\right)<\tilde{q}_{2}\left(\underline{a} \mid \tilde{d}_{2}, \tilde{\theta}_{2}\right)=\tilde{q}_{1}\left(\underline{a} \mid \tilde{\tilde{d}}_{1}, \tilde{\theta}_{1}\right)
$$

が成立するが式(59) と式(60) は明らかに矛盾する. これより, $\tilde{q}_{2}\left(\underline{a} \mid \tilde{\bar{d}}_{2}, \tilde{\theta}_{2}\right)>\tilde{q}_{2}\left(\underline{a} \mid \underline{\tilde{d}}_{2}, \tilde{\theta}_{2}\right)$ を満たす予測結 果の報告はナッシュ均衡解として実現し得ないこと が確認される.

\section{参考文献}

1) 国土交通省: 交通需要推計, 2002.

2) 猪瀬直樹:道路の権力, 文芸春秋, 2003.

3）福本潤也・土谷和之: 需要予測におけるマニピュレーショ ン抑止の制度設計に関する研究, 土木学会論文集, No.772/IV-65, pp.97-114, 2004.

4) 福本潤也:最適契約として捉えたインフラプロジェクトの事 前評価と事後評価, 地域学研究, Vol.33, No.3, pp.103121, 2003.

5) Macho-Stadler, I. and Perez-Castrillo, J.D.: An Introduction to the Economics of Information, Oxford University Press, 2001.
6) Salanie, B.: The Economics of Contracts, MIT Press.

7) Wolfstetter, E. : Topics in Microeconomics: Industrial Organization, Auctions, and Incentives, Cambridge University Press, 2000.

8) Laffont, J.-J. and Martimort, D.: The Theory of Incentives: The Principal-Agent Model, Princeton, 2002.

9) 伊藤秀史:契約の経済理論, 有斐閣, 2003.

10) Bogetoft, P.:Non-Cooperative Planning Theory, SpringerVerlag, 1993.

11) Lawrence, D.B. : The Economic Value of Information, Springer-Verlag, 1999.

12) Osband, K.: Optimal forecasting incentives, Journal of Political Economy, Vol.97, pp.1091-1112, 1989.

13) Kim, S.K.: Limited liabilitiy and bonus contracts, Journal of Economics and Management Strategy, Vol.6, pp.899 $-913$.

14) Park, E.-S.: Incentive contracting under limited liability, Journal of Economics and Management Strategy, Vol.4, pp.477-490.

15) Green, J.R. and Stokey, N.L.: A comparison of tournaments and contracts, Journal of Political Economy, Vol.91, pp.349-364, 1983.

16) Lazear, E.P. and Rosen, S. : Rand-order tournaments as optimum labor contracts, Journal of Political Economy, Vol.89, pp.841-864.

17) 例えば, Axelrod, R.: The Evolution of Cooperation, Basic Books, 1984, 松田裕之訳: つきあい方の科学, ミネルヴァ 書房, 1998.

18)松島斉: 繰返しゲームの新展開 私的モニタリングによる 暗黙の協調, 今井晴雄・岡田章編著, ゲーム理論の新展 開, 勁草書房.

19) Hermalin, B.E., Katz, M.L.: Moral hazard and verifiability: the effects of renegotiation in agency, Econometrica, Vol.59, pp.1735-1753, 1991.

20) 福本潤也・土谷和之:プロジェクト評価の監査制度に関す る研究, 土木学会論文集, No.772/IV-65, pp.79-95, 2004.

需要予測におけるマニピユレーション抑止制度の比較分析

福本潤也

行政が実施する需要予測に対して,マニピュレーションが行われているのではないかとの厳しい批判が社会から投げか けられている. 本論文では, マニピュレーション抑止に有効な制度として, 有限責任制度, トーナメント制度, 繰り返し 取引き制度, 再交渉制度, 監査制度の5つを定義し, 福本・土谷（2004）で提案したリスク負担制度との比較を通じて, それぞれの制度の長短を把握し, 今後の制度設計に向けての有益な知見を探ることを目的とする. 複数制度の比較にあた り，予測作業に携わる分析者が負担するリスクの大きさに特に着目する.

\section{Comparative Analysis on Manipulation Preventing Mechanism of Demand Forecast}

Jun-ya FUKUMOTO

Recently, many criticize that the results of demand forecast analysis is manipulated by Japanese administration. In this paper, we suggest five alternatives of the manipulation preventing mechanism of demand forecast, that is, limited liability mechanism, tournament mechanism, reputation mechanism, renegotiation mechanism and audit mechanism. We compare each mechanism with risk-sharing mechanism which was suggested by Fukumoto and Tsuchiya (2004) and investigate the merits and the demerits of each mechanism to make a set of useful policy recommendations. 